\title{
A personal perspective on four decades of paleolimnology and environmental change research
}

\author{
R. J. Flower
}

Received: 8 June 2016/Accepted: 14 June 2016/Published online: 5 July 2016

(C) The Author(s) 2016. This article is published with open access at Springerlink.com

\begin{abstract}
A personal summary of paleolimnological research activities in the UK and elswehere since the mid 1970s.
\end{abstract}

Keywords Paleolimnology $\cdot$ Diatoms ·

Opportunities

\section{Introduction}

Watching autumn leaves falling on a rain-sodden lawn outside my home-office window, I search for inspiration to make some thematic sense of my seemingly erratic research career investigating lake sediments and their components. The Lifetime Achievement Award from the International Paleolimnological Association in 2015 came as a much-appreciated surprise that I now need to justify! How my particular interests in paleolimnology and environmental change began and developed may even be of some interest to those embarking on a lake-related research career. My

The author was the recipient of a "Lifetime Achievement Award" presented by the International Paleolimnology Association (IPA) in Lanzhou, China, on 4 August 2015.

\section{R. J. Flower ( $\square)$}

Environmental Change Research Centre, UCL

Department of Geography, University College London, Pearson Building, Gower Street, London WC1E 6BT, UK e-mail: r.flower@ucl.ac.uk research orientation probably sprang from early and innate hobby interests in natural and usually wet environments. A first degree in botany and zoology (London) was, however, needed to reveal the awesome complexity and relatedness of life on earth. A Master's degree in marine biology followed and allowed some specialization in estuarine microzooplankton. I cannot point to any particularly keystone mentor at that time during the late 1960s and early 1970s, but a year or so after finishing my M.Sc., an application for a Ph.D. on Lough Neagh in Northern Ireland led to an impromptu meeting with Rick Battarbee at a motorway service station café. There, his enthusiasm, encouragement and attitude rapidly swayed me to join the multidisciplinary group then working on the lough and to focus on diatoms and sediment formation. So, my paleolimnological trajectory began in 1975 by exploring the process links between modern diatom communities and their remains in recent lake sediments. The work appealed because it enabled testing of the assumptions about the quality of sedimentary records of environmental change and, not least, included a significant field work schedule. The study subsequently led to an array of interesting spin-off research opportunities that encompassed lake eutrophication and acidification and a number of regional studies involving recent environmental change and diatom records. These were all largely born out of timely initiatives, chance encounters or technological developments, and diatoms were usually a common theme. So, for me there 
was no career plan as such, just a pressing curiosity about environmental change in time and space; choosing a lake and diatom diversity research pathway was a wise choice.

\section{Lake sediment trapping}

In the 1960s and 1970s, lake eutrophication research in the UK largely centred on Lough Neagh (Northern Ireland), Windermere (England) and Loch Leven (Scotland). At Lough Neagh, Frank Oldfield and Rick Battarbee had pioneered the use of pollen and diatom records in dated sediment cores to chart the impact and history of lake-basin changes, including eutrophication. The 1970s were rather an exciting time for paleolimnology because sediment-dating methods using fallout radionuclides were then developing rapidly (e.g. Appleby and Oldfield 1978), opening up the new field of recent paleolimnology. For Lough Neagh, such sediment dating was used to show that the gross sediment accumulation rate and that of diatoms had increased since the 1900s and markedly so since the 1960s (Battarbee 1978). Plankton diatom communities had also undergone considerable floristic changes during this period, but the links between sediment formation and the quality of recent sediment records in the lough were unclear. Sediment trapping was one way to explore these links and this topic was the focus of my Ph.D. We knew that 'tube' traps overcollected sinking material in the water column and sediment resuspension from the bed of the lake was suspected. It was thought that 'dish' traps, which allow sedimented material to be removed as well as collected, would work better by mimicking hydrodynamic conditions at the natural sediment-water surface. Consequently, several types of sediment trap (Fig. 1) were designed to intercept sedimenting material and enable the flux of sediment components, notably diatoms, to the lake bed to be calculated and evaluated.

Sediment trap collection efficiency was clearly important; it is determined by the trap aspect (height: diameter) ratio and a tendency to over-collect sediment increased up to a ratio of about 8:1. Compared to ${ }^{210} \mathrm{~Pb}$-dated cores, annually sampled tube traps grossly over-collected, by an order of magnitude or more, whereas the dish traps did not (Flower 1991). The former must give an indication of the total downward particulate flux in the water column and so reflect the frequency of sediment resuspension events in the relatively shallow, large $\left(367 \mathrm{~km}^{2}\right)$ and open Lough Neagh. On the other hand, bi-weekly sampled dish traps over-collected only marginally, and qualitatively the composition of these samples accurately tracked seasonal changes in sediment supply. Furthermore, by using the microscope as a quantitative instrument, I found a tight relationship between diatom volume and biogenic silica, which allowed the latter to be calculated for the trapped sediment samples (Fig. 2). The trap samples also produced a plausible signal between catchment erosion, as indicated by their magnetic mineral content, and rainfall (Dearing and Flower 1982). The trapping study clearly identified the sediment surface as the zone where the fidelity of the sediment record was essentially established. The importance of this zone was initially impressed upon me by attending a timely symposium on sediment and freshwater interactions (Golterman 1976), where the complexities of links between these two phases were explored.

Sediment trapping also allows for considerable insight into some of the taphonomic processes that can skew the accuracy of sediment records. The quantitative study by David Ryves on sedimenting material in Lake Baikal was particularly revealing in this respect, by showing that $<1 \%$ of the annual diatom phytoplankton crop in the lake is incorporated into the permanent sediment record. Unsurprisingly, this was principally caused by diatom dissolution losses at the sediment-water interface (Ryves et al. 2003). Later, reworking of the 1970s Lough Neagh diatom data from traps and surficial sediment cores revealed that even in this shallow productive lake with rapidly accumulating sediment, valve damage through dissolution and breakage accounted for the loss of approximately a third of the sedimented diatoms (Ryves et al. 2013). The significance of taphonomic processes in diminishing the qualitative and quantitative accuracy of permanent sediment records (Reed 1998) is often still overlooked. Unless preservation is extremely poor, useful paleoecological trends can however be extracted from most conformable sediment sequences, but differential preservation can interfere strongly with training-set-based numerical reconstructions of environmental variables.

Sediment traps do have a role in paleolimnology, but they are unlikely to provide unequivocal net 


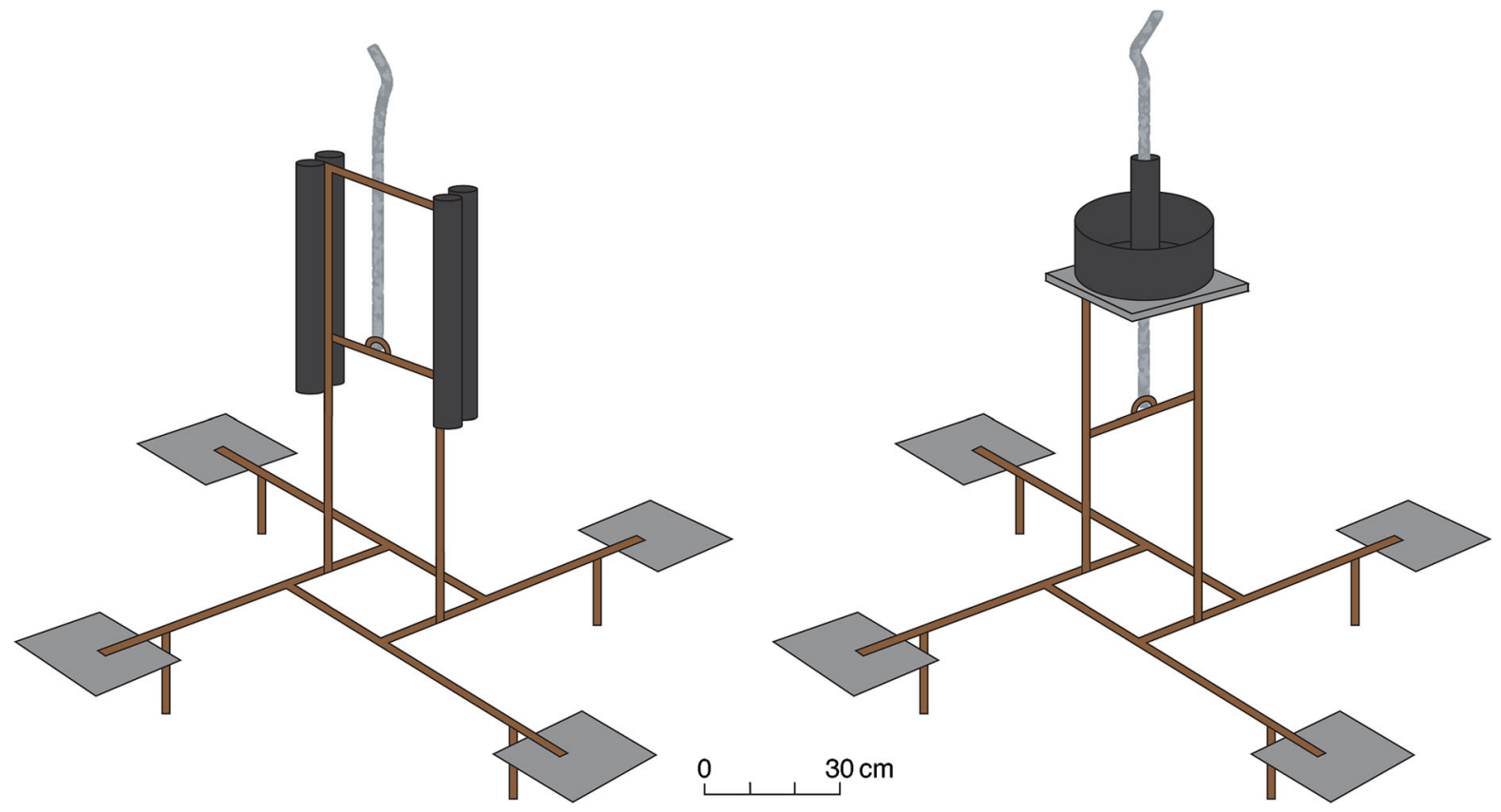

Fig. 1 Sediment trapping. 'Tube' (left) and 'dish' (right) sediment trap types used to study sediment deposition in Lough Neagh, Northern Ireland

measures of sediment deposition and plankton productivity (Bloesch 1996). Some reworked material is always collected in traps so even in the central areas of large lakes traps collect a small proportion of benthic diatoms (Ryves et al. 2003). Despite the potential difficulties of making quantitative estimates, highaspect-ratio tube traps were subsequently incorporated into the UK Acid Waters Monitoring Network lake study, on-going since 1988 . There, the 11 selected UK lakes were all relatively deep, so minimizing redeposition problems associated with over-collection, and annual trap samples provided an excellent qualitative record of diatom species trends (Battarbee et al. 2014). The current generation of timed-sequencing traps, coupled with appropriate environmental sensors, offers excellent opportunities, not only for exploring taphonomy further, but also for revealing relationships among changes in water quality, water-column stability, plankton communities and the biogeochemistry of sedimenting material.

\section{Lake acidification}

Lake acidification emerged as a widespread problem in northern Europe in the late 1970s, threatening salmonid fish stocks in acid-sensitive geological regions. By the early 1980s, diatom paleolimnology was beginning to reveal the extent of acidification in Norwegian and Swedish lakes (Davies and Berge 1980; Renberg and Hellberg 1982). At that time, Rick Battarbee, Stuart Phethean and I made a timely visit to the granitic uplands of Galloway in southwest Scotland to search for evidence of lake acidification. Suspect lochs were selected in rocky, peaty open moorlands or within conifer forestry plantations. The area made for a stark contrast with the nutrient-loaded agricultural lowland landscape of Lough Neagh. The Galloway uplands seemed to me an unlikely area for recent acidification, but the opportunity to test the possibility that these fairly remote lochs were impacted by atmospheric pollution nevertheless seemed interesting. I persisted and joined Rick Battarbee at University College London in 1981 to help form an embryonic UK lake acidification team. Fortuitously for us, sedimentary diatoms, and the ability of diatom species to indicate water $\mathrm{pH}$ (Hustedt 1937-1939), proved to be key in revealing widespread lake acidification in Galloway lochs, both forested and unforested. Also, at about that time I made the acquaintance of the late John Carter, a well-established amateur diatomist who was well versed in the 
Fig. 2 Sediment deposition. Upper, Seasonal changes in gross sedimentation rate determined from bi-weekly sampled 'dish' sediment traps. Lower, seasonal changes in bulk composition of trapped material. Note that the spring diatom crop failed in 1976 and the single peak in sediment (re)deposition followed strong gales in late March (redrawn from Flower 1980; Battarbee and Flower 1993)

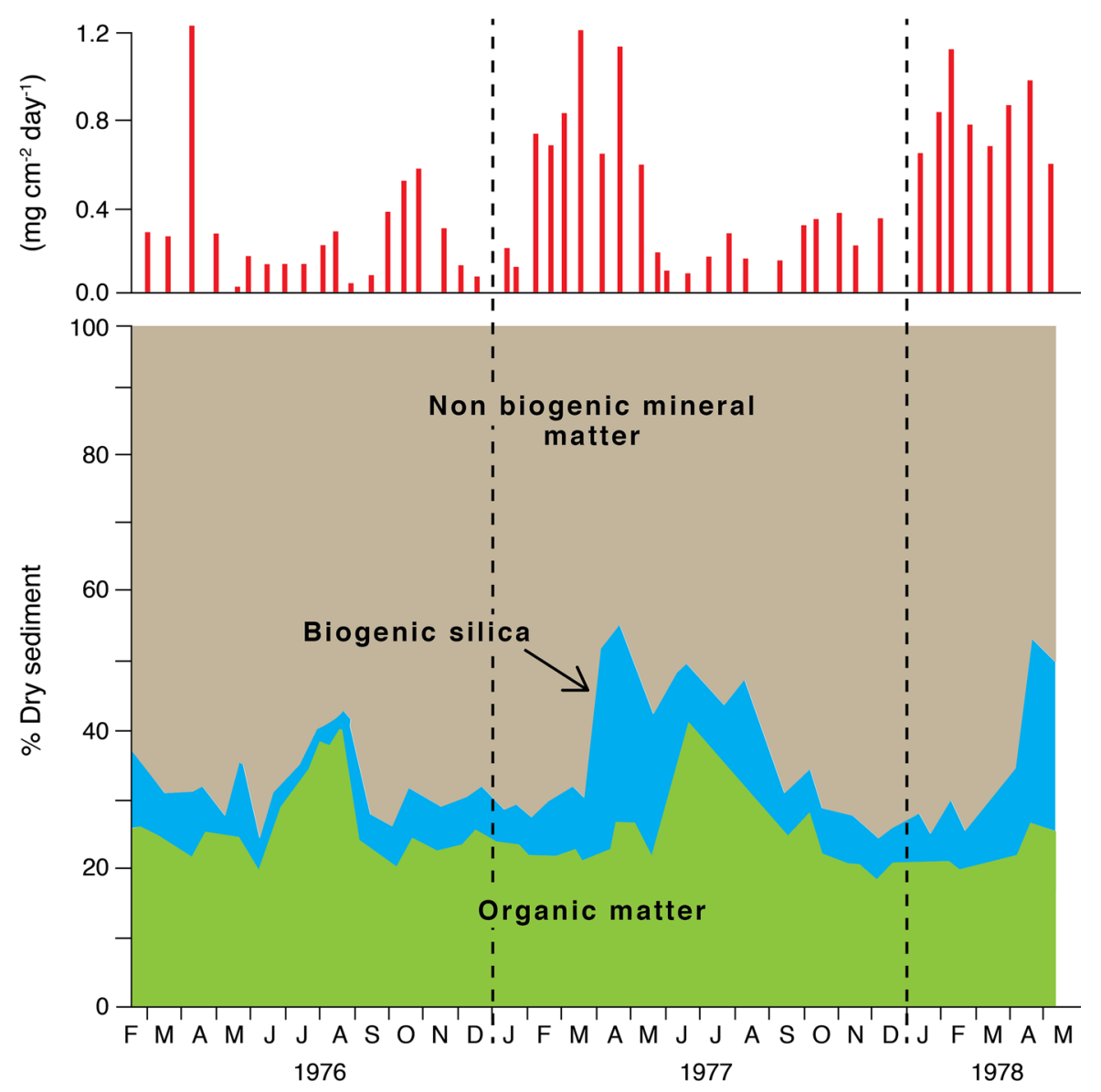

soft-water diatoms of Scotland (Carter and BaileyWatts 1981). His advice on species identifications was both meticulous and generous. The first Galloway core to be analysed for diatoms, from the Round Loch of Glenhead (RLGH), revealed remarkable changes in the diatom species assemblages in the upper sediment. Planktonic Cyclotella kutzinghiana and the unusual Melosira arenti were initially common, but were succeeded by Brachysira vitrea and Eunotia incisa, and in the uppermost sediment, Tabellaria spp. dominated, including $T$. binalis, an acidobiontic strongly acid-tolerant species according to Hustedt's classification. Even before diatom-inferred $\mathrm{pH}$ reconstruction methods were available, the diatom $\mathrm{pH}$ classification was sufficient to indicate that the loch was strongly acidified.

Subsequent sediment dating and other evidence indicated that the Cyclotella decline preceded the industrial period and coincided with earlier accelerated peat inwash, but the acid-tolerant species increased consistently only from the mid-nineteenth century. Despite the initial evidence, publication would require a historical $\mathrm{pH}$ reconstruction, but the identity of several common Tabellaria taxa remained unclear. This taxonomic obstacle needed tackling so that the long forms of Tabellaria flocculosa (Koppen 1975) could be safely discriminated from those of $T$. quadriseptata (Knusdson 1954), a species tolerant of strongly acid water. This was initially tricky in the light microscope, but differences soon became apparent with the aid of scanning electron microscopy (Flower and Battarbee 1985) and the two species were categorized satisfactorily in terms of acidity tolerance. Using the then recently modified Index B diatom-pH regression method (Renberg and Hellberg 1982), we produced a $\mathrm{pH}$ reconstruction curve for the RLGH (Fig. 3) and our first substantive paper on UK lake acidification was published (Flower and Battarbee 1983). Other papers followed and a wealth of paleolimnological evidence concerning acidification 


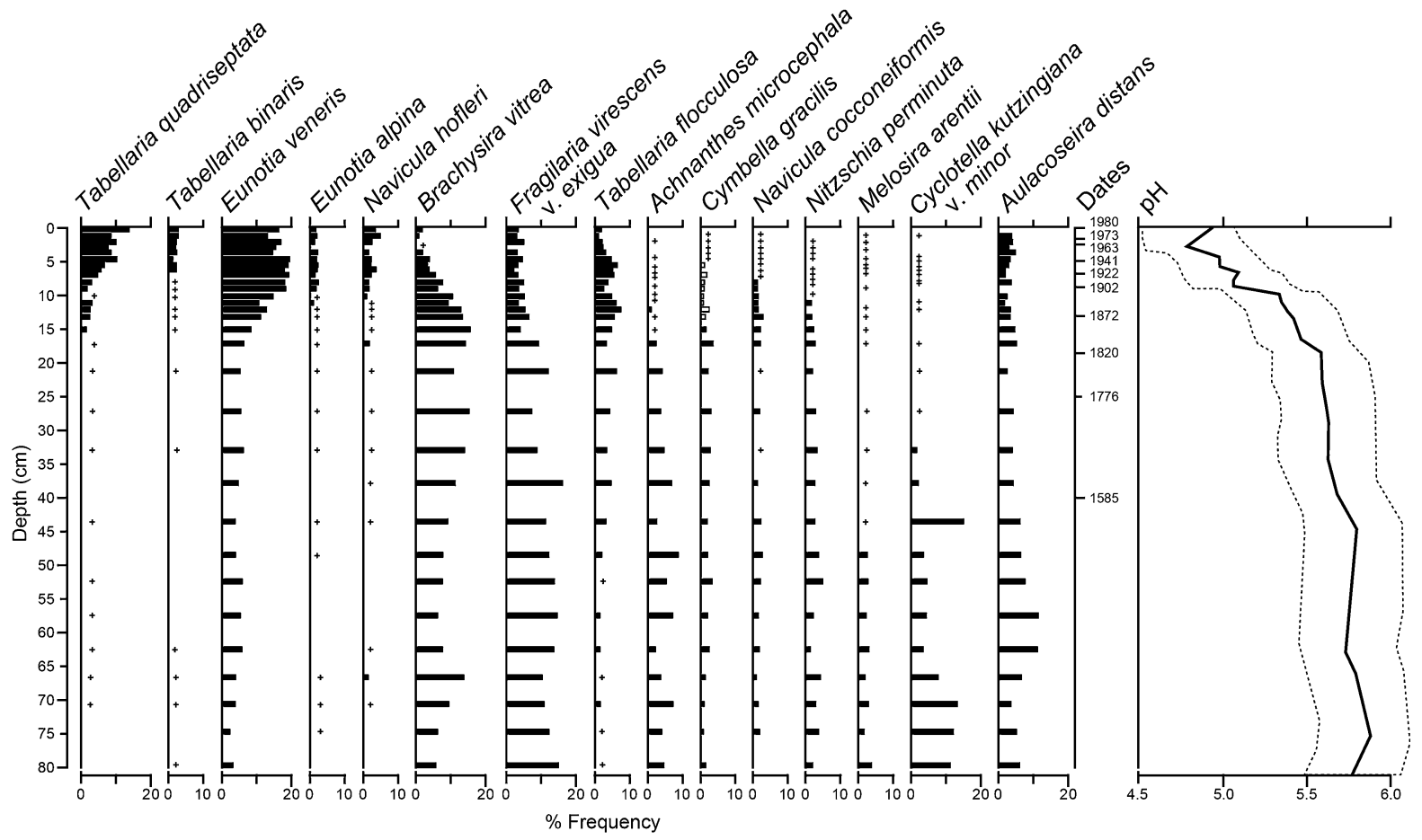

Fig. 3 Lake acidification. The first diatom percentage frequency diagram for a sediment core (1981) from the Round Loch of Glenhead, Galloway, southwest Scotland, showing a sharp decline in diatom-inferred $\mathrm{pH}$ since the latter part of the

and contamination by heavy metals and spheroidal carbonaceous particles (SCPs) (e.g. Battarbee et al. 1989), as well as long-term acidity trends (Jones et al. 1986) was assembled. Supported by robust statistical methods (Birks et al. 1990), the evidence effectively eliminated causes of widespread recent acidification other than atmospheric pollution resulting from fossil fuel combustion.

By the early 1990s, lake acidification paleolimnology began to give way to new lines of related research, including regional mapping of critical acidity loads, NOx emissions and deposition, and monitoring lake and stream recovery responses to declining atmospheric acid pollution (e.g. Battarbee et al. 2014). This was an early warning sign to some researchers to either move into these developing fields or to adapt and refocus by using diatoms in other applications. The latter seemed to offer particularly interesting opportunities for applying diatom and recent paleolimnological techniques more widely. Paleolimnology had bypassed recent environmental change issues in less developed countries of North Africa and in other nineteenth Century (redrawn from Flower and Battarbee 1983, note several diatom names have been revised and the dotted curves indicate $\mathrm{pH}$ error limits)

regions. Also, diatom biodiversity, biogeography and their application to archaeology all seemed particularly attractive new avenues of research at that time. Consequently, appropriate funding initiatives were pursued successfully with a view to diversify and tackle new opportunities in Lake Baikal, North Africa, and elsewhere.

\section{Time-gap filling and Lake Baikal sediments}

By being aware of the power of recent paleolimnology for testing hypotheses about impacts of environmental change, an opportunity arose in the early 1990s to address pollution issues surrounding one of the world's greatest lakes, Lake Baikal. This was made possible by an interesting combination of circumstances, including reforms in the Soviet Union initiated by Gorbachev and the monumental political changes that occurred there in the late 1980s. These changes rapidly increased international scientific collaborations and international exchange visits to the 
former Soviet Union. One outcome was the formation of the 'Baikal International Centre for Ecological Research' (BICER) in 1990, an initiative of the Russian Academy of Sciences, supported by five other countries, to promote research on this ancient lake. The Royal Society (London) provided funding to facilitate UK involvement and, fortuitously for us, opinions on lake pollution impacts were then conflicting. Clearly, there was a role here for recent paleolimnology and the Society funded Donald Monteith and me to visit the lake in 1991 and discuss research ideas with Mikhail Grachev, the then-Director of the Limnological Institute at Irkutsk. Meetings went well and, despite considerable Russian interest at the time in long cores, we made a case for using diatoms in twentieth-century sediment to help inform the debate about pollution and ecological change. The initial visit led to a succession of UCL-partnered Lake Baikal research projects that continue to the present under the tutelage of Anson Mackay (UCL).

Our visits in 1991 and 1993 were a revelation concerning this magnificent rift valley lake, which rightly deserves superlatives in regard to its species diversity, endemicity, great depth and length of sediment record. Baikal's deep-water, inter-glacial sediments are rich in diatoms and the BICER-inspired Baikal Drilling Programme (BDP) produced $600 \mathrm{~m}$ of sediment extending to 10 million years BP. The detailed diatom stratigraphic record over the past 1.3 million years is an exemplary account of diatom species responses to climate change (Khursevich et al. 2005). Our paleolimnology work in the early 1990s focussed mainly upon collecting short cores, first using a gravity corer (Glew 1989) modified to close automatically in deep water and then a novel box sampler (Flower et al. 1995a, b), both built at UCL by Jim Chambers MBE (Fig. 4). Diatom analysis of ${ }^{210} \mathrm{~Pb}$-dated short cores (Mackay et al. 1998) revealed little evidence of recent nutrient enrichment of the lake (Fig. 5), and trace metal contamination was also equivocal (Boyle et al. 1998). Nevertheless, low concentrations of SCPs were present since the 1940s (Rose et al. 1998), notably in the south basin (Fig. 5). Such results were not, however, intended to encourage complacency about the lake's pristine state because pesticide residues were bioaccumulating in the Nerpa seal population (Tsydenova et al. 2003), and in the last decade, observations on the lake's south basin (O. Timoshkin, pers. commun.) indicate that effluent is causing water quality problems.
Given the relative insensitivity of Baikal's extremely deep-water sediments to pollution, we suspected that atmospherically transported pollutants might still be affecting the Baikal region significantly. So, it seemed logical to investigate mountain lake sediments nearby Lake Baikal. With considerable good fortune and good will, we were able to make a rather challenging field excursion via an old ex-Afghanistan Mil helicopter, to obtain short cores from several small lakes in the Kamar Daban Mountains (Fig. 6, noteparking aircraft close to near-pristine lakes is unwise). Sedimentary evidence of heavy metal contamination was found, but this was much lower than for similar sites in Western Europe; SCPs were, however, moderately higher than in Baikal (Flower et al. 1996). The diatoms were a surprise, for we found, in one high corrie lake, a large planktonic centric diatom, Pliocaenicus costatus v. sibericus (Skabitch.) Flower, Ozornina and Kuzmina, abundant in modern samples. This diatom was until then only known from fossil deposits and subsequent sediment core analysis showed that it had increased markedly in this lake since the 1890s (Flower et al. 1998).

The diversity of diatoms in the Baikal region is remarkable and in Lake Baikal itself, approximately half the flora is endemic. When we began to examine our fresh diatom material and consult the classical papers on Baikal diatoms by Skvortzov (e.g. Skvortzov 1937), it was clear that most taxa were known only as line-drawings. The taxonomy of some common planktonic diatoms (Fig. 5) needed attention (Flower 1993), but it was the benthic diatoms that showed the greatest diversity and species complexity. The dearth of research on these diatoms in the latter part of the twentieth century was very apparent, and in the early 1990s David Williams (NHM, UK) and I realized that the endemic benthic flora was so neglected that a reference collection, combined with LM and SEM studies, was needed. A timely grant from the British Government's Darwin Initiative in 1996 enabled us not only to provide significant infrastructure funding for diatom research at the Limnological Institute, but also to make extensive modern collections from the lake's entire $>2000$-km-long littoral zone. Mapping the distribution of shallow-water species was begun (Flower et al. 2005) and the project was able to involve an international team of diatom taxonomy specialists to help record diatom diversity. The task is on-going and it is good to know that a multi-volume 


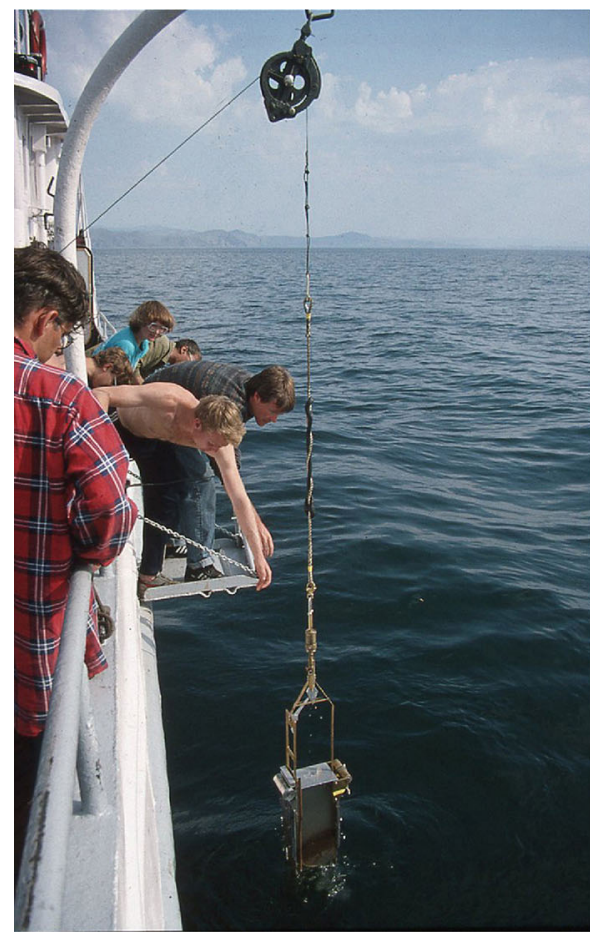

Fig. 4 Lake Baikal. Left, surficial sediment coring in Lake Baikal in 1993 with Anson Mackay and Don Monteith (left and centre of the photograph, respectively) using a novel box corer

iconographic account of the diatoms in Lake Baikal is now in production (Kulikovskiy et al. 2015). For paleolimnology, however, the challenge remains to find a sediment coring location with abundant benthic diatoms. Unfortunately, coring the classic 33-m depth location near the Olhon Gate reported on by Skvortzov (1937) yielded only non-accumulating silty sand, a result that concluded my last field visit to the lake.

\section{Paleolimnological opportunities and North African lakes}

The seeds of interest in North African lakes began to develop during a chance conversation in early 1978 with several Ph.D. student colleagues in a Northern Irish bar. As a result, we formed an expedition society that facilitated a rather exhaustive exploratory visit to Moroccan lakes in June-September 1979. That trip produced a number of valuable and memorable experiences; some were even relevant to paleolimnology. Particularly rewarding was sharing and

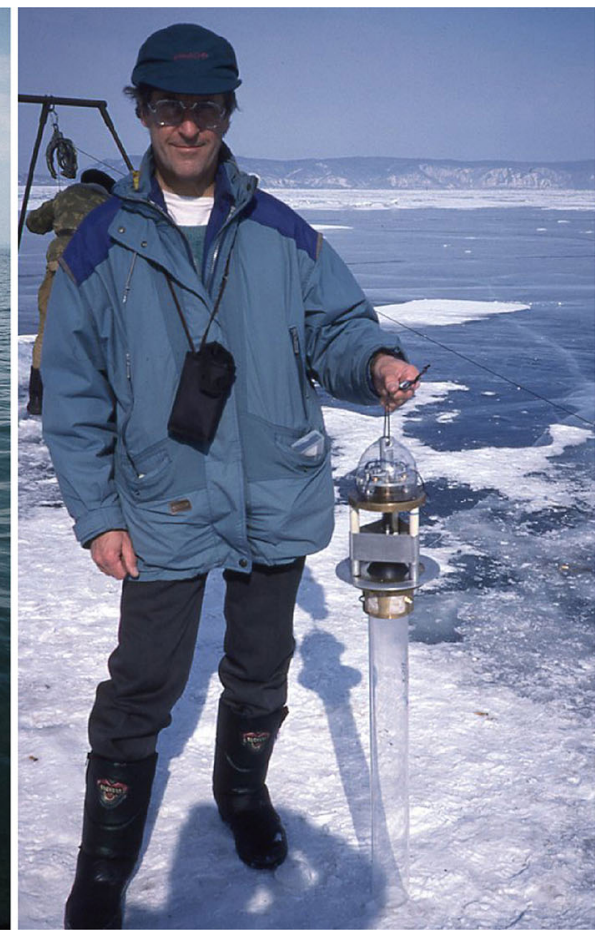

deployed from the RV Titov. Right, a Glew sediment corer modified by Jim Chambers M.B.E (pictured) to close automatically at depth

developing opinions with expedition colleagues and others knowledgeable in geology, geochemistry, ornithology, entomology, palynology and aquatic biology. These exchanges were educative and highlighted the need for multidisciplinarity in tackling many environmental change problems, especially those in developing countries. For Morocco at that time, as now, the most pressing issue threatening lakes and wetlands was over-exploitation of natural resources, which included land-use changes and soil erosion, and hydrological modifications and water abstraction, leading to loss of habitat quality. Identifying the relative impacts of such disturbances clearly required not only a variety of scientific skills, but a wider appreciation of the value of unbiased scientific evidence. Land owners, environmental engineers, government planning agencies all require such evidence, but the information pathway from evidence to management policy is a difficult one. In areas where documentary records of past environmental changes are often incomplete, lake sediment archives can provide invaluable information. Our first Moroccan 


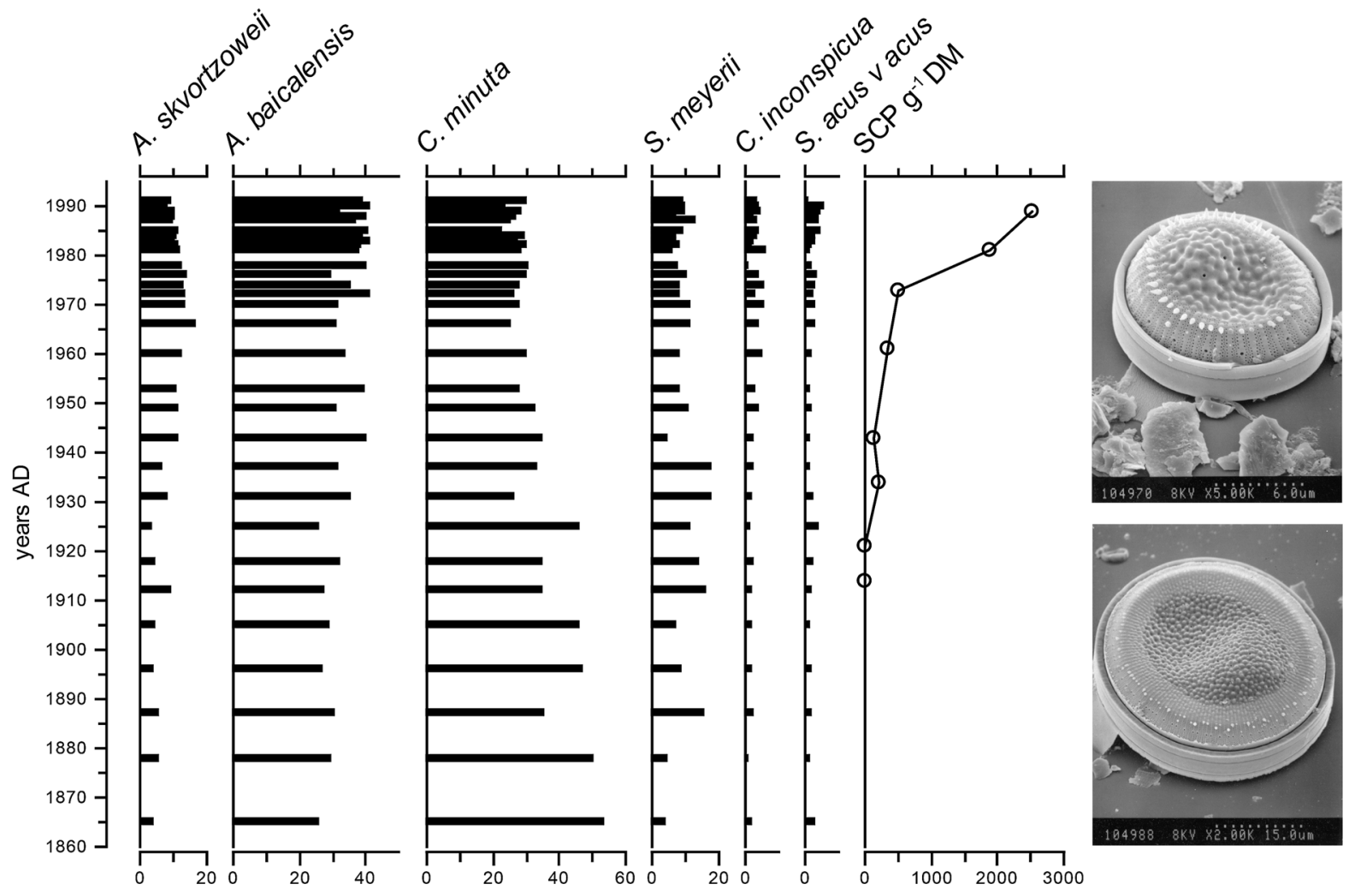

Fig. 5 Lake Baikal. Left, the first high-resolution diatom percentage frequency diagram for a dated surficial sediment core (BAIK6) from the lake's south basin (after Flower et al. 1995a, b; Mackay et al. 1998) showing little evidence of

trip included a visit to one particular lake, Dayat er Roumi (lake of the Romans), which served as a prime example of a site that had undergone dramatic, but largely unrecorded twentieth century changes.

As a consequence of a combination of factors, Dayat er Roumi (Fig. 7) was in fact one of only two lakes out of the six we visited in 1979 that yielded 'good' (complete, datable) cores. The sediment record in this turbid lake showed a large peak in magnetic minerals (Fig. 7), indicative of accelerated soil erosion that culminated in the 1970s (Flower et al. 1984). So, how could we relate this peak to landscape changes? Answering this required several follow-up investigations and in 1984 three Moroccan lakes were cored with the invaluable help of John Dearing, Ian Foster and others. We used a variety of sediment corers and one interesting experience concerned use of the Livingstone corer to retrieve a Holocene record from Dayat er Roumi. Using a boat platform, we cored twentieth century eutrophication but increasing particulate contamination by SCPs. Right, SEM images of two endemic planktonic diatoms, Cyclotella minuta (upper) and C. ornata (lower)

through about $7.5 \mathrm{~m}$ of cohesive clayey sediment, but no further, despite unchanged sediment composition. After some thought we realized that the sediment consistency was such that effort exerted on the magnesium zirconium alloy corer rods caused them to bend and trap against the casing inner wall. The retrieved core had a thin black layer of charred cereal chaff near the core base and ${ }^{14} \mathrm{C}$ dating indicated this to be only a 1000 years old $(1080 \pm 60 \mathrm{Cal} \mathrm{BP})$ (unpublished). For these fairly compacted minerogenic sediments, the mean annual accumulation rate was relatively high $(>0.6 \mathrm{~cm})$ and so we probably missed the Roman occupation period by some $5 \mathrm{~m}$, a depth not possible to achieve without auxiliary power equipment. This valedictory lesson in sediment penetrability proved to be applicable to many lowland North African lakes.

Using a 1.3-m mini Mackereth corer (courtesy of Coventry University), good cores were obtained in 


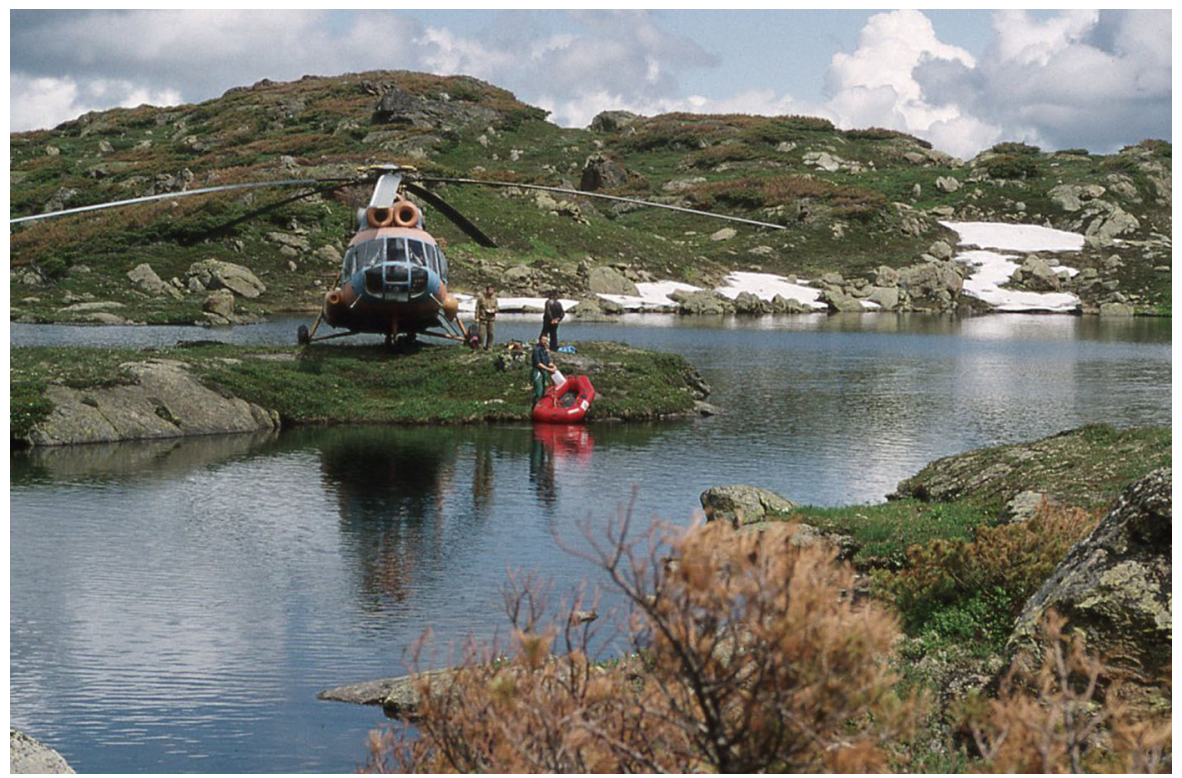

Fig. 6 Field work in Siberia. Lake Kholodny in the Kamar Daban Mountains on the eastern side of Lake Baikal, visited to collect sediment cores (1994) with field workers Neil Rose, Sergei Politov and A. Yakushin (pictured)
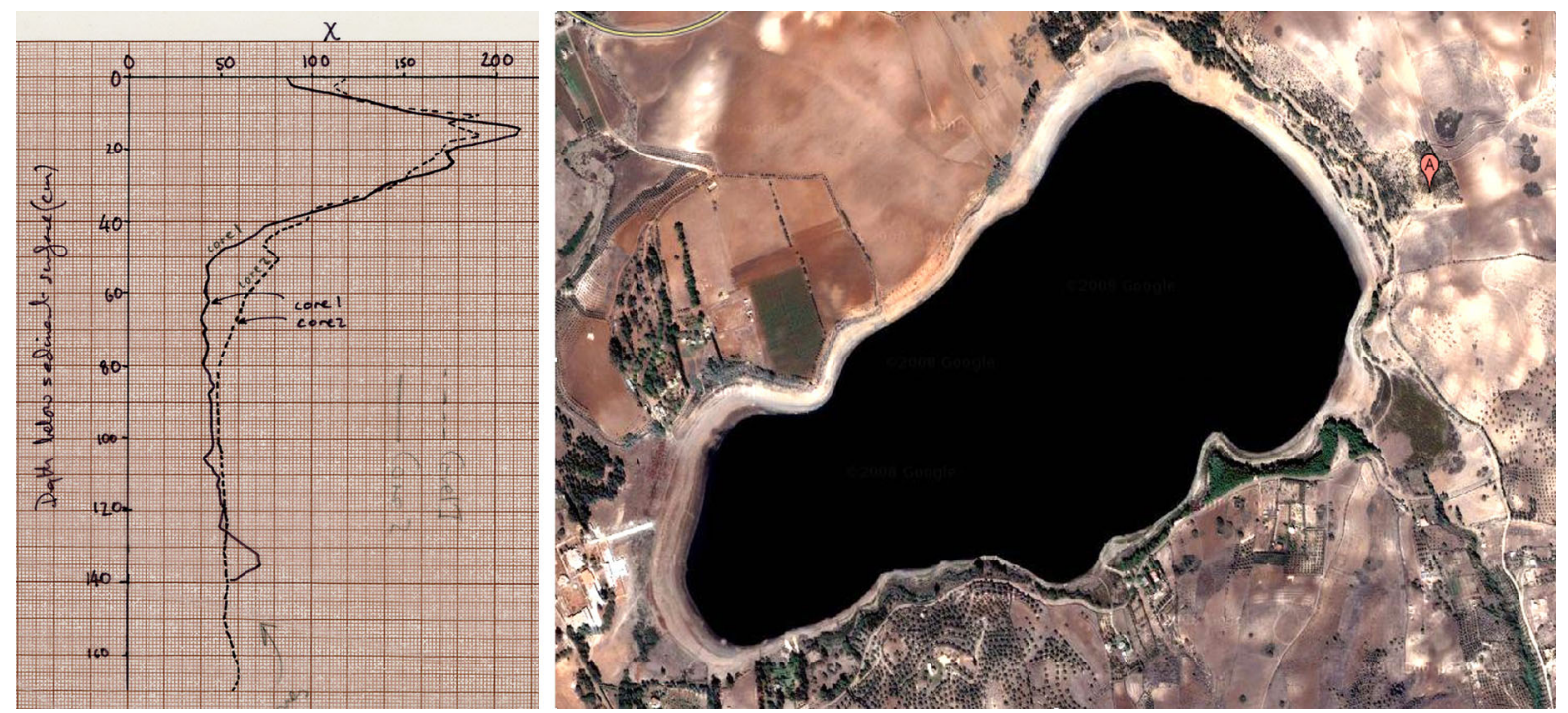

Fig. 7 Recent paleolimnology in North Africa. Left, original whole core magnetic susceptibility profiles for our first two cores (1979) from Dayat er Roumi. Right, a satellite image showing denuded soils and exposed Miocene limestone country rock east of the lake

1984 from the three lakes and pollen and diatom analyses were subsequently performed to reveal more about regionality and the nature of recent environmental changes. Results for Dayat er Roumi were rewarding (Fig. 8), as refined new analyses showed that the lake suffered from rapid siltation and suppressed diatom plankton (Flower et al. 1989). During the twentieth century Quercus woodland was cleared and soil erosion followed, and the sediment accumulation rate exceeded $2 \mathrm{~cm}$ year ${ }^{-1}$ by the 1960s. Landscape changes, mainly related to land cultivation, were the principal cause of diminished lake status, 


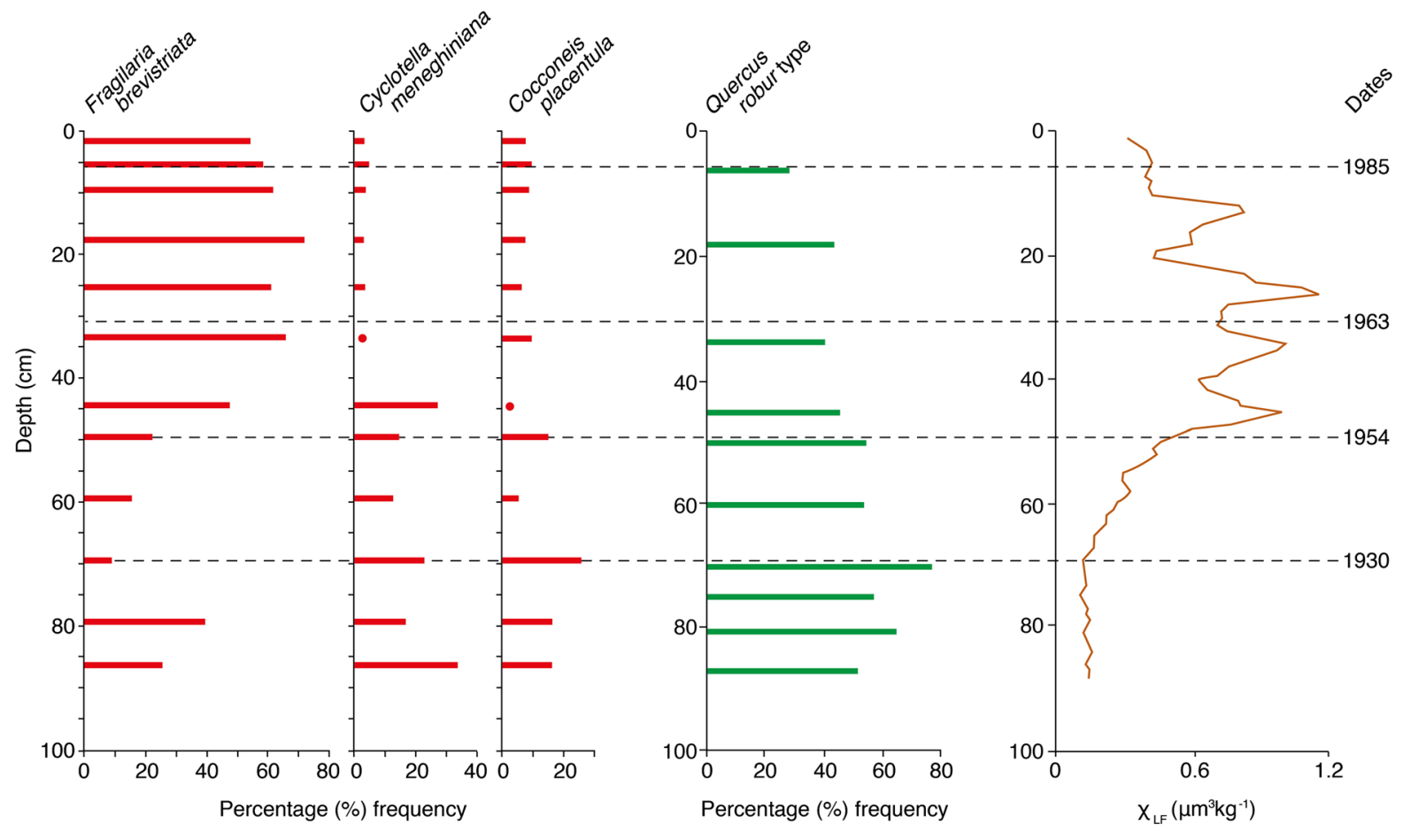

Fig. 8 Dayat er Roumi. A stratigraphic multi-proxy diagram for a dated sediment core from the lake showing a Quercus pollen decline, suppression of diatom phytoplankton (Cyclotella

caused first by increased surface soil erosion and then by deep gully erosion in the northeastern sector of the catchment (Foster et al. 1986). Such changes were subsequently found to be typical of other lakes in Morocco where land-use intensification, siltation, lake level changes and eutrophication are common problems. At one lake, Aguelmane Azigza, where human disturbance was lower, follow-up work indicated that the lake was remarkably susceptible to inter-annual rainfall variations (Flower and Foster 1992). Frustratingly, little evidence could be found for this in the deep-water sediments, but exposed, steeply shelving marginal sediments did contain thick laminations of calcified aquatic macrophyte remains.

Building upon our Moroccan lake experiences, we reasoned that a paleolimnological approach could be usefully applied across North Africa where lake salinization, siltation and eutrophication were all common problems. A large EU project grant (CASSARINA-Change, Stress, Sustainability and Aquatic ecosystem Resilience In North Africa) enabled us in 1996 to begin investigations of lakes and lagoons in meneghiniana) and the post-1950 increases in eroded soil magnetic minerals (re-drawn from Flower et al. 1984, 1989)

Morocco, Tunisia and Egypt (Flower 2001). Cooperators in North Africa included Mohamed Ramdani (Morocco), Fethi Ayache (Tunisia) and Mahmoud Ahmed (Egypt); the partnership notably also included Hilary Birks (Norway). Lakes near populated coastal zones seemed likely to be most impacted by human activities, yet many such sites retained considerable biological importance. Consequently, we focussed on nine such sites and collected a suite of cores from west to east North Africa, spanning some $3500 \mathrm{~km}$. Sedimentary diatom records were not always well preserved so the macrofossils and pollen skills provided by Hilary Birks and Sylvia Peglar proved invaluable for reconstructing past ecological changes. Likewise, pollen and macrofossil remains proved helpful for establishing sediment chronology. Problems also arose as a consequence of fallout ${ }^{210} \mathrm{~Pb}$ diminishing strongly across North Africa in sympathy with rainfall, making knowledge of the timing of exotic plant introductions a useful marker for calibrating radiometric chronologies (Appleby et al. 2001). 
Contrary to expectations, we found that, rather than salinization, the aquatic ecology of several of our sites had been strongly affected by water freshening during the twentieth century. This was most marked for the Nile Delta lakes (Birks et al. 2001a) where agricultural returns had increased, especially after construction of the Aswan High Dam in the 1960s. One example was Lake Manzala, a large, multi-purpose water body, $>1000 \mathrm{~km}^{2}$ in area, that had undergone dramatic ecological changes (Fig. 9) and the habitat shifted from freshwater swamp (pre-twentieth century) to salt marshes until around 1960, then to freshwater wetlands (Birks et al. 2001a). Changes in recent sediment accumulation rates showed no clear regional pattern except in the delta lakes where they all declined in response to reduced sediment supply around the 1960s. Despite high contemporary dissolved N and P concentrations, the diatom assemblages oddly showed no clear responses (high turbidity may be a factor), but later sediment $\delta^{15} \mathrm{~N}$ values did indicate heavy use of agro-fertilizers (Oczkowski et al. 2011). Interestingly, metal contamination was generally low, but SCP contamination was more marked, increasing since the 1940s, mainly from European sources, but with greater local contributions since the 1970s (Rose et al. 2003). Pesticide contamination was a notable problem at the Moroccan and Egyptian (Peters et al. 2001) sites and species turnover was very high in all nine master cores (Birks et al. 2001b). Collectively, the paleo-data provided convincing evidence that water management and landuse intensification were, in one way or another, the greatest drivers of diminished biological quality in these North African sites during the twentieth century.

Notwithstanding the intrinsic interest of many North African lake systems, further research funding from the EU's International Cooperation scheme required the inclusion of environmental management tools and modelling. For lakes and lagoons, this meant real-time data, not least from instrumented catchments, so that eco-hydrological models could be calibrated. We proposed three key sites amenable for hydrological modelling and, with major contributions by Julian Thompson (UCL), Erik Rasmussen and Ole Peterson (DHI), and with EU funding in 2002, another phase of our North African research began-

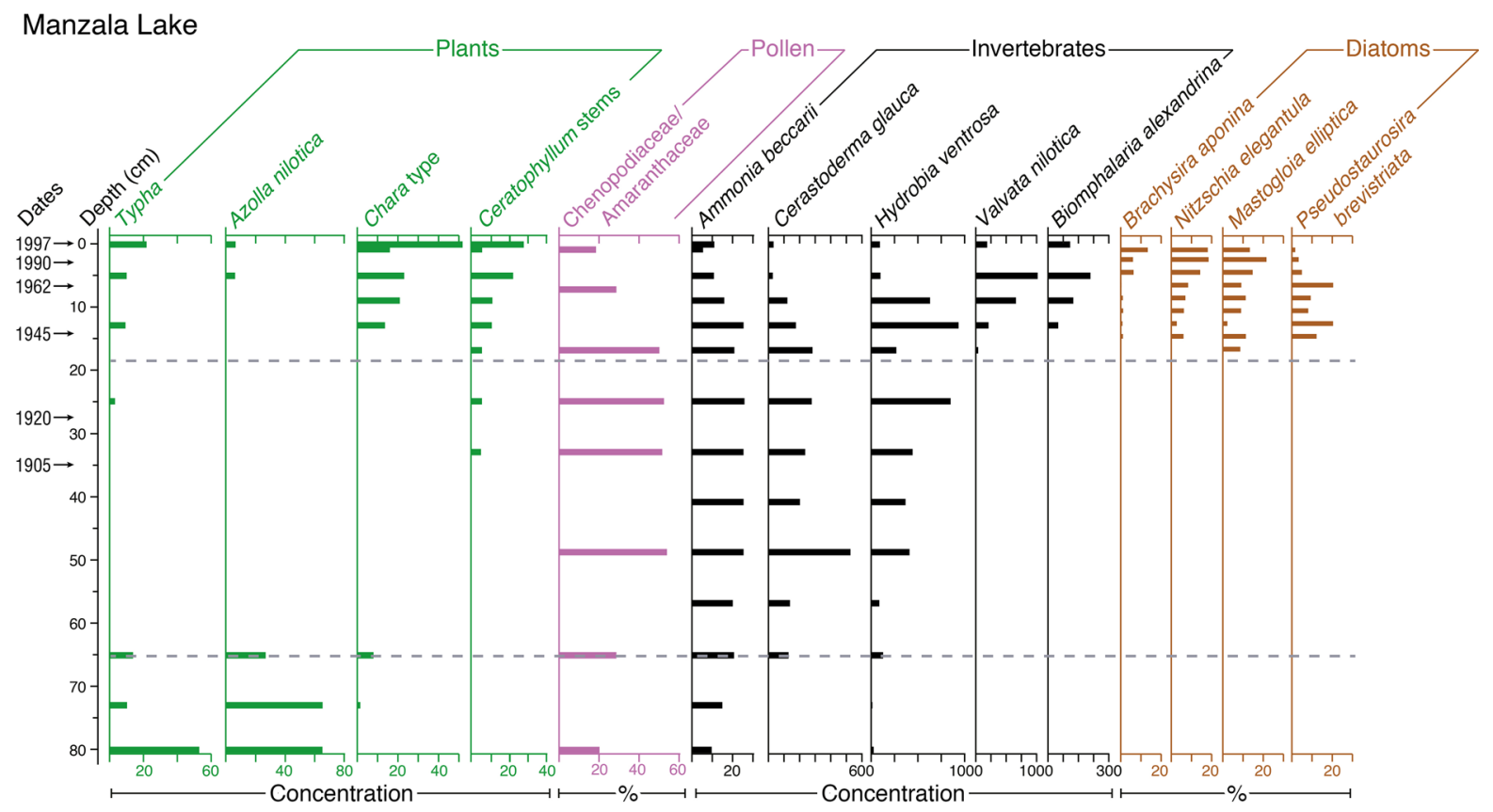

Fig. 9 Recent paleolimnology in North Africa (CASARINA). A combined stratigraphic multi-proxy macro- and microfossil diagram for cores from Lake Manzala, a lake on the northern margin of the Nile delta. Note the species changes indicate transitions from freshwater swamp to salt marsh and then to freshwater wetland. (Figure combined and re-drawn from Birks et al. 2001a; Flower et al. 2001) 
MELMARINA (Monitoring and modelling costal lagoons: Making management tools for aquatic resources in North Africa). We knew that setting up harmonized procedures for regular site monitoring in Morocco, Tunisia and Egypt was no simple task. Nevertheless, with our North African colleagues, the sites were duly instrumented in a fairly coordinated manner (Thompson et al. 2009). Some light relief for me was provided by retaining a small paleolimnological project component, though only to supply information on lake volume changes by measuring siltation rates. A project outcome of particular interest was the development of nutrient-change simulations for reducing eutrophication and increasing submerged vegetation in Lake Manzala (Rasmussen et al. 2006). Meetings with stakeholder groups, including representatives of the Port Said Governorate were instructive for the diversity of interests expressed and for the necessity to integrate water resource and aquatic ecosystem management (Thompson and Flower 2009). Bridging the gulf between paleo-scientists, neo-scientists, economists and policy makers is often challenging and discussions focused on management implications for site reclamation and the economic value of land, as opposed to water and fisheries considerations. Debating politically inspired questions, such as 'how much of a lake can we reclaim while retaining its biodiversity and ecosystem services?' were problematic for me. Consequently, rather than pursue such political engagement, I was able to divert my attention to another Egyptian lake of special interest for an entirely different reason, its archaeological history and sediment records.

\section{Geoarchaeology and Egyptian paleolimnology}

Egyptian archaeology has a long and colourful history, but until the 1990s, the potential of lake sediment records for revealing landscape changes and environmental impacts of cultural development during the emerging Egyptian civilization, had been neglected. The intriguing possibility of tackling these issues became apparent during one of our EU-supported explorative field visits to Lake Qarun. This lake, $70 \mathrm{~km}$ southwest of Cairo, yielded several respectable $\sim 1$-m cores that provided information about lake salinization and diatom preservation (Flower et al. 2006). Counter-intuitively, the lake level had risen progressively since the late nineteenth century as the salinity tripled from around 100 to $300 \mathrm{ppt}$. The explanation lies in Egypt's perennial irrigation programme, whereby Nile barrages and agricultural reforms led to irrigation water surpluses. Washout of surface soil salts is a well-known way of preparing soils for agriculture in the Faiyum and these salts are transferred to the lake. There are similarities to the Salton Sea in California, but one big difference is that Lake Qarun is sustained by fresh Nile water. This flows through the Hawara Pass where we were able to inspect nearby 12th Dynasty pyramids. Excavated tunnels in the Hawara pyramid were inundated by unevaporated saline water, supporting the idea that the inundation was late nineteenth century at best (Keatings et al. 2007). Diatoms in the ancient mud bricks also indicated the use of fresh Nile water (Flower 2006). We thought these findings interesting and an obvious inference at the time was that the monuments were in some way related to ancient water regulation and past lake levels (Hassan 1986), surely an intriguing line of investigation.

Collaborating with Fekri Hassan (UCL Archaeology) in 2003, we secured significant funding to undertake Holocene coring of Lake Qarun. However, what seemed an attractive 'do-able' project became quite a challenge. First, getting a coring rig and associated platform equipment on-site was a novel experience and here Richard Niederreiter (UWITEC) proved to be an excellent facilitator. Second, central lake sediment below $\sim 7 \mathrm{~m}$ depth was so consolidated that retrieving the piston corer was not possible without partially submerging the platform! Third, our $\$ 6000$ equipment import deposit was only partly returned, and in Egyptian pounds that could not be exchanged. Fourth, subsequent bulk radiocarbon dating did not yield a monotonically declining activity depth profile. Seeds extracted from near the core base did however indicate a date near 2000 years BP and lake salinity was inferred to increase from around the sixteenth century (Abu-Zied et al. 2011). The question arose as to what the next step might be? Clearly, the answer was to collect more cores!

Given the lack of time spanned by the central lake core and reduced funding, coring the marginal shore deposits of this formerly much larger lake seemed an obvious option. So, in April 2008 and with the help of Mohamed Hamdan, we drill cored on the lake's southern shore to a depth of $21.3 \mathrm{~m}$ (Fig. 11, left). 
The core penetrated down into coarse sands, but immediately above these there was a surprise, the sediment was thinly laminated and varve-like in appearance. The initial results attracted collaboration with a Japanese team and they were able to retrieve piston cores from the shore and the lake. Despite whole-core dating problems, progress was made when plant macrofossil fragments extracted from the sharp interface between lake sediment and basal sands yielded a date of $9945 \pm 213 \mathrm{Cal}$ BP (Yamada et al. 2011). The thin early Holocene laminations were also confirmed as varves, being triplicate structures composed of planktonic diatoms, calcite and clastic layers (Flower et al. 2012). The lack of dating control for the whole core continued to give pause for thought, so our interest moved to diatom taxonomy (Flower et al. 2013) (Fig. 10) and to the core section containing the basal sand-lacustrine sediment transition (Fig. 11, right). The latter proved rather informative regarding the lake's origin; microscopic analysis indicated the basal sands were aeolian, containing re-worked forams, including pre-Quaternary taxa, but no diatoms. Above the sand, silty clay layers graded into thin annual layers of calcite and then into calcite and lacustrine microfossil layers including ostracods and diatoms (Fig. 12). The diatoms were mainly planktonic forms, largely comprising Aulacoseira granulata and Cyclotella spp., and their abundances increased up section together with carbonates and magnetic minerals. Since Nile flood waters are (and likely were) rich in diatoms (Talling et al. 2009) and Nile sediment has high magnetic susceptibility (Foster et al. 2008), we interpreted these changes as indicating a relatively gradual, rather than catastrophic, filling of the lake

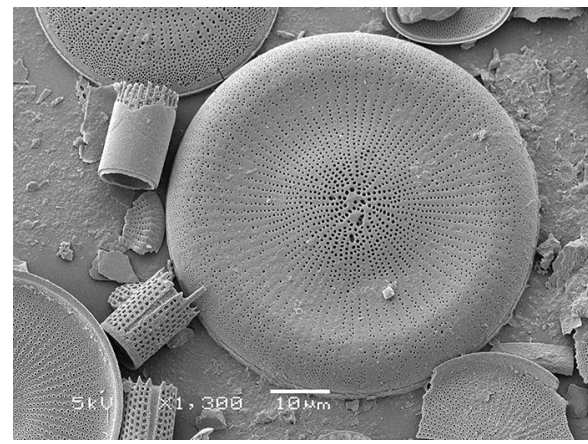

Fig. 10 Egyptian paleolimnology. SEM images of two planktonic diatoms. Left, Stephanodiscus neoaegypticus Flower, from Holocene lake sediments in the Faiyum Depression. Right, basin that occurred over a period of more than 50 years.

\section{To conclude}

The research path I have outlined benefited from a combination of factors that included curiosity-driven persistence and more than a modicum of good fortune regarding the timeliness of research and funding opportunities. Undoubtedly, diatoms are a common thread through much of my research, whether they were in the sedimentary archives of Scottish lochs, North African wetlands or in Siberian lakes. One simple reason is that careful discrimination of species according to a firm replicable taxonomy (Flower 2005) is a precursor for measuring paleoecological change. Despite the remarkable advances in techniques, for me, morpho-species remain the 'real deal'-after all, how else can we usefully perceive, appreciate and communicate the ecological nature of past and contemporary ecosystems without using species concepts. That is not to say paleo-eDNA does not have an important role, but it is unlikely to be adequate for paleo-productivity and species diversity, although discriminating differential species losses might well be worth a try. Probably the greatest challenge for paleolimnology remains the lack of good dating control for many unlaminated pre twentiethcentury sediments (Seddon et al. 2013). From my experiences, I can add this is particularly so for sediments in many sites subjected to Mediterraneantype climates! Maybe one day the problem will be solved by inserting a handy age-detector probe into fresh sediment, but I guess that is still some time away.

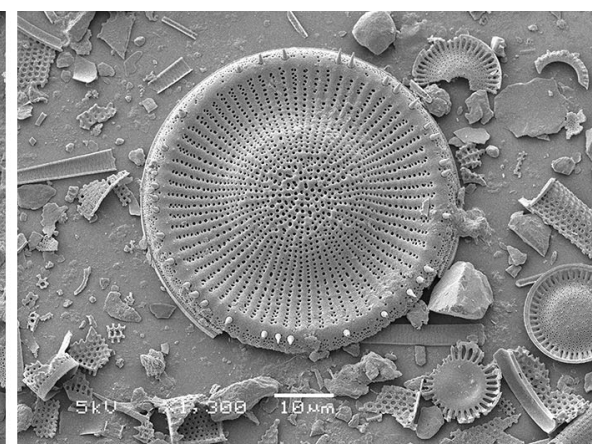

Stephanodiscus galilliensis Håkansson \& Ehrlich, a fairly common diatom in early Holocene lake sediments of Lake Qarun 
Fig. 11 Lake Qarun. Left, drill coring on the southern shore of Lake Qarun in April 2008. Middle, photograph of a split core section from the basal section of a 20.3-mlong core from the lake's southern margin showing the sharp transition from coarse aeolian sands to laminated silty clays that grade into thin layers of diatoms, calcite and silt. Right, a litho-stratigraphic diagram for this split core section
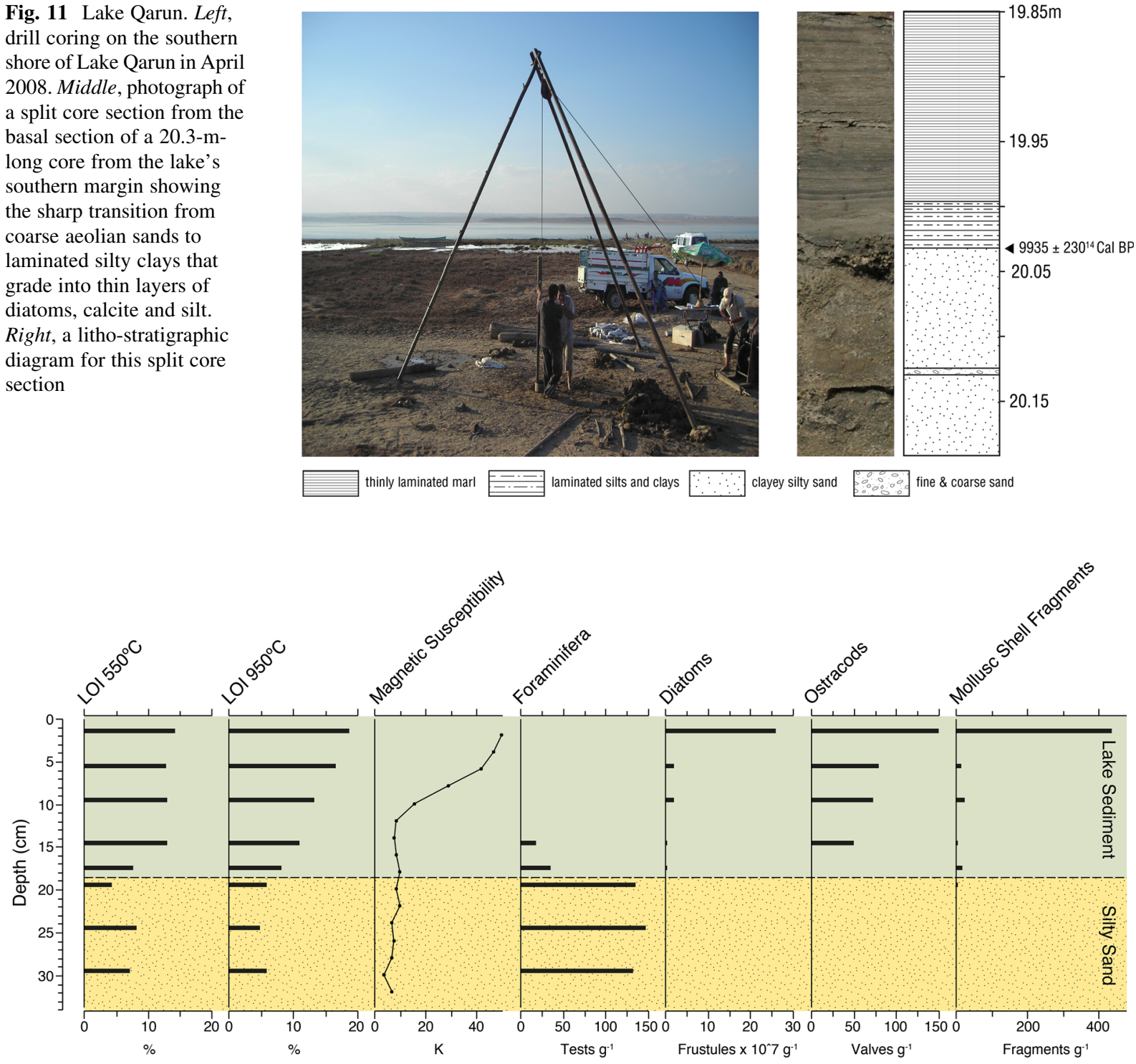

Fig. 12 Lake Qarun. A bio-lithostratigraphic diagram of the 20.3-m, lake-margin core basal section, showing proportional changes in organic matter (LOI, loss on ignition), carbonates,

magnetic minerals and in microfossil abundances across the sand-lake sediment transition (dotted line)

I can summarize my experiences into five themes that could be educative for young, aspiring paleolimnologists. First, be alert in recognising emerging fields of interest. The 1970s and 1980s were particularly notable for paleolimnological opportunities in lake eutrophication and acidification. New techniques and technical developments are integral to paleolimnology and their emergence continually gives rise to new opportunities. Second, consider how combinations of new and established paleo-techniques can be best applied to help test hypotheses about specific environmental problems, locally or globally. Many paleotools are now available, from microfossils to biomarker molecules, as described in the comprehensive series of Kluwer books, Developments in Paleoenvironmental Research. They now need to be applied more widely. Much work has rightly been undertaken on climate change reconstructions, but I would suggest 
that a focus on the ecological implications for aquatic diversity is also important, particularly in less developed regions. Third, look for research gaps in an establishing research field. For example, in the 1980s, Lake Baikal was a site where recent paleoenvironmental change research was lacking in on-going studies. Elsewhere, gaps still exist in biogeographic areas and between disciplines. Fourth, develop a multidisciplinary approach and where possible team up with colleagues at least as motivated and interested as one's self. Fifth, actively promote/apply/disseminate the values of paleolimnology whenever possible, to broaden awareness of its potential. Despite the plethora of current threats to freshwaters (Smol 2008), there is still a way to go in many countries to inform environmental management policy makers of the contributions sediment records can make to monitoring, assessing and modelling environmental change.

As I eventually finish drafting this article, I am reminded that the now-fallen autumn leaves possibly hold a message, to sign off, step down and fill the remaining years with new pursuits, maybe golf or sky diving. Reality is that by choosing a lifetime career studying lakes and their multi-component sediment archives, many of us will remain hostage to these interests. The mind scientific thrives off curiosity and...returning to those fallen leaves, how much carbon did they capture? What is the fate of those brown leaf-like stains on the pathway (assuming they are part dissolved organic matter, DOM)? Will DOM export and 'global browning' of freshwaters significantly affect diatom communities? ... So, do take care if you embark on a career such as I, you sign up to be entertained or perplexed by many such questions for the duration of compos mentis.

Acknowledgments I wish to thank all those people who have collaborated with me so generously here in the UK, particularly colleagues in the ECRC-UCL, and those in the overseas countries where I have had the good fortune to work. Not least, I am grateful for the support, financial and otherwise, I have received from an array of institutions. Miles Irving kindly prepared the artwork.

Open Access This article is distributed under the terms of the Creative Commons Attribution 4.0 International License (http:// creativecommons.org/licenses/by/4.0/), which permits unrestricted use, distribution, and reproduction in any medium, provided you give appropriate credit to the original author(s) and the source, provide a link to the Creative Commons license, and indicate if changes were made.

\section{References}

Abu-Zied RH, Keatings K, Flower RJ, Leng MJ (2011) Benthic foraminifera and their stable isotope composition in sediment cores from Lake Qarun, Egypt: changes in water salinity during the past $\sim 500$ years. J Paleolimnol 38:261-283

Appleby PG, Oldfield F (1978) Calculation of lead-210 dates assuming a constant rate of supply of unsupported ${ }^{210} \mathrm{~Pb}$ to the sediment. Catena 5:1-8

Appleby PG, Birks HH, Flower RJ, Rose N, Ramdani M, Kraïem MM, Fathi AA (2001) Sediment accumulation rates and radiometric dating of recent sediments from nine North African wetland lakes (the Cassarina Project). Aquat Ecol 36:347-367

Battarbee RW (1978) Observations on the recent history of Lough Neagh and its drainage basin. Philos Trans R Soc B 281:303-345

Battarbee RW, Flower RJ (1993) The recent sediments of Lough Neagh. In: Wood RB, Smith RV (eds) Lough Neagh: the ecology of a multipurpose water resource. Kluwer, Dordrecht, pp 113-132

Battarbee RW, Stevenson AC, Rippey B, Fletcher C, Natkanski J, Wik M, Flower RJ (1989) Causes of lake acidification in Galloway: a palaeoecological evaluation of the relative roles of atmospheric contamination and catchment change for two acidified sites with non-afforested catchments. J Ecol 77:651-672

Battarbee RW, Simpson G, Shilland E, Flower RJ, Kreiser A, Yang H (2014) Recovery of UK lakes from acidification: an assessment using combined palaeoecological and contemporary diatom assemblage data. Ecol Indic 37:365-380

Birks HJB, Line JM, Juggins S, Stevenson AC, Ter Braak CJF (1990) Diatoms and $\mathrm{pH}$ reconstruction. Philos Trans R Soc Lond B 327:263-278

Birks HH, Birks HJB, Flower RJ (2001a) Recent ecosystem dynamics in nine North African lakes. Aquat Ecol 36:461-478

Birks HH, Peglar SM, Boomer I, Flower RJ, Ramdani M, Appleby PG, Ramdani M, Kraïem M, Fathi AA, Abdelzaher H (2001b) Palaeolimnological responses of nine North African lakes to recent environmental changes and human impacts detected by macrofossil and pollen analyses. Aquat Ecol 36:405-430

Bloesch J (1996) Towards a new generation of sediment traps and better measurement/understanding of settling particle flux in lakes and oceans: a hydrodynamical protocol. Aquat Sci 58:283-296

Boyle JF, Mackay AW, Rose NL, Flower RJ, Appleby PG (1998) Sediment heavy metal record in Lake Baikal: natural and anthropogenic sources. J Paleolimnol 20:135-150

Carter JR, Bailey-Watts AE (1981) A taxonomic study of diatoms from standing waters in Shetland. Nova Hedwigia 33:513-628

Davies RB, Berge F (1980) Atmospheric deposition in Norway during the last 300 years as recorded in SNSF lake sediments 11 Diatom stratigraphy and inferred $\mathrm{pH}$. In: Drabløs D, Tollan A (eds) Ecological impact of acid precipitation, proceedings of an international conference, Sandefjord, Norway. SNSF Project, Oslo, pp 270-271 
Dearing JA, Flower RJ (1982) The magnetic susceptibility of sedimenting material trapped in Lough Neagh, NorthernIreland, and its erosional significance. Limnol Oceanogr 27:969-975

Flower RJ (1980) A study of sediment formation, transport and deposition in Lough Neagh, Northern Ireland, with special reference to diatoms. D.Phil. Thesis. University of Ulster

Flower RJ (1991) Field calibration and performance of sediment traps operated in a holomictic eutrophic lake. J Paleolimnol 5:175-188

Flower R (1993) A taxonomic re-evaluation of endemic $C y$ clotella taxa in Lake Baikal, Siberia. Nova Hedwigia 106:203-220

Flower RJ (2001) Change, stress, sustainability and aquatic ecosystem resilience in North African wetland lakes during the 20th century: an introduction to integrated biodiversity studies within the CASSARINA Project. Aquat Ecol 35:261-280

Flower RJ (2005) A review of diversification trends in diatom research with reference to taxonomy and environmental applications using examples from Lake Baikal and elsewhere. Proc Calif Acad Sci 56:107-128

Flower RJ (2006) Diatoms in ancient building materials: application of diatom analysis to Egyptian mud bricks. Nova Hedwig Beih 130:245-264

Flower RJ, Battarbee RW (1983) Diatom evidence for the recent acidification of two Scottish lochs. Nature 305:130-133

Flower RJ, Battarbee RW (1985) The morphology and biostratigraphy of Tabellaria quadriseptata (Bacillariophyceae) in acid waters and lake sediments in Galloway, southwest Scotland. Br Phycol J 20:69-79

Flower RJ, Foster IDL (1992) Climatic implications of changes in lake level at Lac Azigza (Morocco). Bull Geól Soc France 163:91-96

Flower RJ, Dearing JD, Nawas R (1984) Sediment supply and accumulation in a small Moroccan lake: an historical perspective. Hydrobiologia 112:81-92

Flower RJ, Stevenson AC, Dearing JD, Foster IDL, Airey A, Rippey B, Wilson JPF (1989) Catchment disturbance inferred from paleolimnological studies of three contrasted sub-humid environments in Morocco. J Paleolimnol 1:293-322

Flower RJ, Mackay AW, Rose NL, Boyle JL, Dearing JA, Appleby PG, Kuzmina A, Granina LZ (1995a) Sedimentary records of recent environmental change in Lake Baikal, Siberia. Holocene 5(3):323-327

Flower RJ, Monteith DT, Mackay AW, Appleby PG (1995b) A new box-corer for collecting undisturbed samples of soft sub-aquatic sediments. J Paleolimnol 14:101-111

Flower RJ, Politov S, Rippey B, Rose NL, Appleby PG, Stevenson AC (1996) Sedimentary records of the extent of and impact of atmospheric contamination in a remote Siberian mountain lake. Holocene 7:161-178

Flower RJ, Ozornina SP, Kuzmina A, Round FE (1998) Pliocaenicus taxa in modern and recent material mainly from eastern Russia. Diatom Res 13:39-62

Flower RJ, Dobinson S, Ramdani M, Kraïem MM, Ben Hamza C, Fathi AA, Abdelzaher HMA, Birks HH, Appleby PG, Lees JA, Shilland E, Patrick ST (2001) Recent environmental change in North African wetland lakes: diatoms and other stratigraphic evidence from nine sites in the Cassarina Project. Aquat Ecol 35:369-388

Flower RJ, Pomazkina G, Rodionova Y, Williams DM (2005) Local and meso-scale diversity patterns of benthic diatoms in Lake Baikal. In: Poulin M (ed) 17th international diatom symposium 2002. Biopress Limited, Bristol, pp 69-92

Flower RJ, Stickley C, Rose NL, Peglar S, Fathi AA, Appleby PG (2006) Environmental change at the desert margin: an assessment of recent paleolimnological records in Lake Qarun, Middle Egypt. J Paleolimnol 35:1-24

Flower RJ, Keatings K, Hamdan M, Hassan FA, Boyle JF, Yamada K, Yasuda Y (2012) The structure and significance of early Holocene laminated sediments in the Faiyum Depression (Egypt) with special reference to diatoms. Diatom Res 27:127-140

Flower RJ, Keatings K, Hamdan M, Hassan FA (2013) Stephanodiscus Ehr. species from Holocene sediments in the Faiyum Depression (Middle Egypt). Phytotaxa 127:66-80

Foster IDL, Dearing JD, Airey A, Flower RJ, Rippey B (1986) Sediment sources in a Moroccan lake-catchment. Water Res 5:320-334

Foster IDL, Oldfield F, Flower RJ, Keatings K (2008) Trends in mineral magnetic signatures in a long core from Lake Qarun, Middle Egypt. J Paleolimnol 40:835-849

Glew J (1989) A new trigger mechanism for sediment samplers. J Paleolimnol 2:241-243

Golterman HL (ed) (1976) Interactions between sediments and freshwater. Pudoc, Amsterdam

Hassan FA (1986) Holocene lakes and prehistoric settlements of the Western Faiyum, Egypt. J Archaeol Sci 13:486-501

Hustedt F (1937-1939) Systematische und ökologische Untersuchungen uber den Diatomeen-Flora von Java Bail und Sumatra. Archiv für Hydrobiol (Supplement) 15 \& 16

Jones VJ, Stevenson AC, Battarbee RW (1986) Lake acidification and the land-use hypothesis: a mid-post-glacial analogue. Nature 322:157-158

Keatings K, Tassie GI, Flower RF, Hassan FA, Hamdan MAR, Hughes M, Arrowsmith C (2007) An examination of groundwater within the Hawara Pyramid, Egypt. Geoarchaeology 22:533-554

Khursevich G, Prokopenko AA, Fedenya SA, Tkachenko LI, Williams DF (2005) Diatom stratigraphy during the past 1.25 Ma, new results from BDP-96 and BDP-99 drill cores. Quat Int 136:95-104

Knusdson BM (1954) The ecology of the diatom genus Tabellaria in the English Lake District. J Ecol 42:345-358

Koppen JD (1975) A morphological and taxonomic consideration of Tabellaria (Bacillariophyceae) from the northeastern United States. J Phycol 11:236-244

Kulikovskiy M, Lange-Bertalot H, Kuznetsova I (2015) Lake Baikal: hotspot of endemic diatoms. Iconogr Diatomol 35:1-656

Mackay AM, Flower RF, Kuzmina AI, Granina LZ, Rose NL, Appleby PG, Boyle JF, Battarbee RW (1998) Diatom succession trends in recent sediments from Lake Baikal. Philos Trans R Soc B 353:1011-1055

Oczkowski AJ, Flower RJ, Thompson JR, Ayache F, Ahmed MH, Ramdani M, Turner S (2011) Evidence of North Africa's green revolution preserved in sedimentary organic 
matter deposited in three coastal lagoons. Ecol Appl 21:1708-1717

Peters AJ, Jones KC, Flower RJ, Appleby PG, Ramdani M, Kraïem M, Fathii AA (2001) Recent environmental change in North African wetland lakes: a baseline study of organopesticide contaminant residues in nine sites in the Cassarina Project. J Paleolimnol 35:449-459

Rasmussen EK, Petersen OS, Thompson JR, Flower RF, Ahmed M (2006) Hydro-dynamic-ecological model analyses of the water quality of Lake Manzala (Nile delta, Northern Egypt). Hydrobiologia 622:195-220

Reed JM (1998) Diatom preservation in the recent sediment record of Spanish saline lakes: implications for paleoclimate studies. J Paleolimnol 19:129-137

Renberg I, Hellberg T (1982) The pH history of lakes in southwestern Sweden, as calculated from the sub-fossil diatom flora of the sediments. Ambio 11:30-33

Rose NL, Appleby PG, Boyle JF, Mackay AW, Flower RJ (1998) The spatial and temporal distribution of fossil fuel derived pollutants in the sediment record of Lake Baikal. J. Paleolimol 20:151-162

Rose NL, Flower RJ, Appleby PG (2003) Spheroidal carbonaceous particles (SCPs) as indicators of atmospherically deposited pollutants in North African wetlands of conservation importance. Atmos Environ 37:1655-1663

Ryves DB, Jewson DH, Sturm M, Battarbee RW, Flower RJ, Mackay AW, Granin N (2003) Quantitative and qualitative relationships between planktonic diatom communities and diatom assemblages in sedimenting material and surface sediments in Lake Baikal, Siberia. Limnol Oceanogr 48:1643-1661

Ryves DB, Anderson NJ, Flower RJ, Rippey B (2013) Diatom taphonomy and silica recycling in two freshwater lakes and their implications for inferring past lake productivity. J Paleolimnol 49:411-430

Seddon A et al (2013) Looking forward through the past: identification of 50 priority research questions in palaeoecology. Ecology 102:256-267

Skvortzov BV (1937) Bottom diatoms from Olhon Gate of Baikal Lake, Siberia. Philipp J Sci 62:293-377

Smol JP (2008) Pollution of lakes and rivers: a paleoenvironmental perspective, 2nd edn. Wiley, Oxford

Talling JF, Sinada F, Taha OE, Sobhy EMH (2009) Phytoplankton: composition, development and productivity. In: Dumont HJ (ed) The Nile, origin, environments, limnology and human use. Monographiae biologicae 89. Springer, Dordrecht, pp 431-462

Thompson JR, Flower RJ (2009) Environmental science and management of coastal lagoons in the Southern Mediterranean Region: key issues revealed by the MELMARINA Project. Hydrobiologia 622:221-232

Thompson JR, Flower RJ, Ramdani M, Ayache F, Ahmed MH, Rasmussen E, Petersen O (2009) Hydrological characteristics of three North African coastal lagoons: insights from the MELMARINA project. Hydrobiol 622:45-84

Tsydenova O, Minh TB, Kajiwara N, Batoev V, Tanabe S (2003) Recent contamination by persistent organochlorines in Baikal seal (Phoca sibirica) from Lake Baikal, Russia. Mar Pollut Bull 48:749-758

Yamada K, Yasuda Y, Shinozuka Y, Yonenobu H (2011) Changes of sedimentological environment during the Holocene in Lake Qarun, Faiyum Basin, Egypt. Japan Geoscience Union Meeting, May 22-27, Chiba (Japan). Abstract on-line: www2.org/meeting/2001/yokou/APE3126_PDF 